\title{
A Facile Synthetic Route to a Family of Mn(III) Monomers and their Structural, Magnetic and Spectroscopic Studies
}

Jones, Leigh; Barra, Anne-Laure; Ryder, Alan G.; Brechin, Euan K.; Collison, David; Innes, Eric J.L.; Sanz, Sergio; Kelly, Brian; Houton, Edel

\section{European Journal of Inorganic Chemistry}

DOI:

10.1002/ejic.201601124

Published: 01/11/2016

Peer reviewed version

Cyswllt i'r cyhoeddiad / Link to publication

Dyfyniad o'r fersiwn a gyhoeddwyd / Citation for published version (APA):

Jones, L., Barra, A-L., Ryder, A. G., Brechin, E. K., Collison, D., Innes, E. J. L., Sanz, S., Kelly, B., \& Houton, E. (2016). A Facile Synthetic Route to a Family of Mn(III) Monomers and their Structural, Magnetic and Spectroscopic Studies. European Journal of Inorganic Chemistry, 2016(32), 5123-5131. https://doi.org/10.1002/ejic.201601124

\footnotetext{
Hawliau Cyffredinol / General rights

Copyright and moral rights for the publications made accessible in the public portal are retained by the authors and/or other copyright owners and it is a condition of accessing publications that users recognise and abide by the legal requirements associated with these rights.

- Users may download and print one copy of any publication from the public portal for the purpose of private study or research.

- You may not further distribute the material or use it for any profit-making activity or commercial gain

- You may freely distribute the URL identifying the publication in the public portal ?
}

Take down policy

If you believe that this document breaches copyright please contact us providing details, and we will remove access to the work immediately and investigate your claim. 


\section{A Facile Synthetic Route to a Family of Mn(III) Monomers and their Structural, Magnetic and Spectroscopic Studies}

Edel Houton, ${ }^{[\mathrm{b}]}$ Brian Kelly, ${ }^{[\mathrm{b}]}$ Sergio Sanz, ${ }^{[\mathrm{c}]}$ Eric J. L. Mclnnes, ${ }^{[\mathrm{e}]}$ David Collison, ${ }^{[\mathrm{e}]}$ Euan K. Brechin, ${ }^{[\mathrm{c}]}$ Anne-Laure Barra, ${ }^{[[d]}$ Alan G. Ryder ${ }^{*[b]}$ and Leigh F. Jones ${ }^{\star[a, b]}$

[a] L. F., Jones

School of Chemistry

Bangor University

Alun Roberts Building, Deiniol Road, Bangor, Wales, UK.

E-mail: leigh.jones@bangor.ac.uk

[b] E. Houton, B. Kelly, A. G. Ryder.

School of Chemistry

NUI Galway

University Road, Galway, Ireland. [d] A.-L. Barra.

LNCMI-CNRS

Grenoble, Cedex, France.

[e] E. J. L. McInnes, D. Collison

School of Chemistry

University of Manchester

Oxford Road, Manchester, England, UK.

[c] S. Sanz, E. K. Brechin.

EaStCHEM School of Chemistry

University of Edinburgh

David Brewster Road, Edinburgh, Scotland.

Supporting information for this article is given via a link at the end of the document. 
Abstract: We report a rapid and facile synthetic route to the synthesis of a family of $\mathrm{Mn}$ (III) monomers of general formula $\left[\mathrm{Mn}(\mathrm{III}) \mathrm{F}_{3}\left(\mathrm{H}_{2} \mathrm{O}\right)\left(\mathrm{L}_{1-6}\right)\right] \cdot x \mathrm{H}_{2} \mathrm{O} \cdot y \mathrm{MeOH}$ (where $\mathrm{L}_{1}=2,2^{\prime}-$ Bipyridyl, $x=2$, $y=0$ (1'); $\mathrm{L}_{2}=1,10^{\prime}$-Phenanthroline, $x=y=0\left(\mathbf{2}^{\prime}\right) ; \mathrm{L}_{3}=6$-Methyl2,2'-dipyridyl, $x=y=0$ (3), $\mathrm{L}_{4}=4$,4-Dimethyl-2,2'-dipyridyl, $x=2, y=$ 0 (4), $\mathrm{L}_{5}=5,5^{\prime}$-Dimethyl-2,2'-dipyridyl, $x=0, y=0.5$ (5) and $\mathrm{L}_{6}=5$ Chloro-1,10-phenanthroline, $x=y=0$ (6). Magnetic susceptibility and magnetisation experiments have been employed to elucidate the anisotropic $D$ tensor for each family member (ranging from -3.01 $\mathrm{cm}^{-1}$ in 2 ' to $-4.02 \mathrm{~cm}^{-1}$ in 5), while multi-frequency / high-field EPR spectroscopic measurements and subsequent simulations gave similar values for complexes 1' $\left(-4.25 \mathrm{~cm}^{-1}\right), \mathbf{2}^{\prime}\left(-4.03 \mathrm{~cm}^{-1}\right), 4(-3.90$ $\left.\mathrm{cm}^{-1}\right)$ and $5\left(-4.04 \mathrm{~cm}^{-1}\right)$. The terminal Mn-F vibrational stretches in 1'-6 have been probed using Raman spectroscopy.

\section{Introduction}

Commercially available sources of the $\mathrm{Mn}$ (III) ion are relatively scarce and this has connotations for synthetic chemists working in many facets of research. ${ }^{[1]}$ For instance, $\mathrm{Mn}(\mathrm{III})$ species are common catalytic reagents ${ }^{[2]}$ in various organic transformations centred on oxidative radical cyclizations ${ }^{[3]}$ while manganese complexes have been extensively studied as model compounds towards elucidating the function of specific metalloenzymes. ${ }^{[4]}$ Extensive investigations into the beneficial incorporation of $\mathrm{F}^{-}$ anions when acting as a co-catalyst within Pd-catalysed Stille, ${ }^{[5]}$ Suzuki-Miyaura ${ }^{[6]}$ and Hiyama ${ }^{[7]}$ cross-coupling procedures have shown improved catalytic performances due to their triple-role contributions, although control of fluoride ion concentration is required. ${ }^{[7]}$ In the field of molecular magnetism, the $\mathrm{Mn}$ (III) ion is an excellent source of single-ion anisotropy and when aggregated into polymetallic cages can often lead to molecules displaying slow relaxation of the magnetisation and magnetic bistability. ${ }^{[8]}$ Synthetic chemists in this field predominantly rely on the redox manipulation of $\mathrm{Mn}(\mathrm{II}), \mathrm{Mn}(\mathrm{IV})$ and $\mathrm{Mn}(\mathrm{VII})$ precursors to produce $\mathrm{Mn}$ (III) rich polymetallic cages. ${ }^{\left[{ }^{[9]}\right.}$ An alternative, and rather attractive, strategy would be to synthesise new monometallic $\mathrm{Mn}(\mathrm{III})$ complexes.
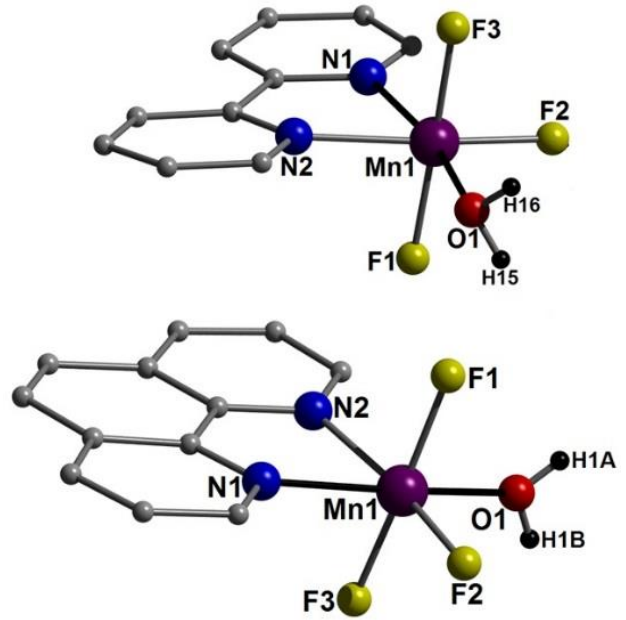

Figure 1. Crystal structures of $\left[\mathrm{MnF}_{3}\left(\mathrm{H}_{2} \mathrm{O}\right)\left(\mathrm{L}_{1}\right)\right] \cdot 2 \mathrm{H}_{2} \mathrm{O}$ (1') (top) and $\left[\mathrm{MnF}_{3}\left(\mathrm{H}_{2} \mathrm{O}\right)\left(\mathrm{L}_{2}\right)\right]\left(\mathbf{2}^{\prime}\right)$ (bottom). Colour code: Purple $(\mathrm{Mn})$, Red $(\mathrm{O})$, Blue $(\mathrm{N})$, Grey $(\mathrm{C})$, Yellow $(\mathrm{F})$ and Black $(\mathrm{H})$.

The strategic incorporation of F-bridges within paramagnetic 3d cages also holds significance in the fields of molecular magnetism and is perhaps best highlighted by the extensive work of Winpenny and co-workers who have developed high yielding synthetic routes to numerous F- bridged $\mathrm{Cr}$ (III) complexes, including elegant, extended families of homo- (i.e. $\left[\mathrm{Cr}_{8}\right],{ }^{[10]}\left[\mathrm{Cr}_{9}\right]^{[11]}$ and $\left.\left[\mathrm{Cr}_{10}\right]^{[12]}\right)$ and heterometallic $\left(\left[\mathrm{Cr}(\mathrm{III})_{7} \mathrm{M}_{1}\right] ; \mathrm{M}=\right.$ $\mathrm{Ni}(\mathrm{II}), \mathrm{Co}(\mathrm{II}), \mathrm{Fe}(\mathrm{II}), \mathrm{Mn}(\mathrm{II}), \mathrm{Cd}(\mathrm{II}))^{[13]}$ wheels and horseshoes. ${ }^{[14]}$ Examples of F-bridged $3 d-4 f$ assemblies were recently presented by Bendix and co-workers when discussing the targeted formation of a family of $\left[\mathrm{Gd}(\mathrm{III})_{2} \mathrm{M}(\mathrm{III})_{2}\right]$ molecular magnetic refrigerants (where $\mathrm{M}=\mathrm{Cr}$, Fe, Ga from $\mathrm{CrF}_{3}, \mathrm{FeF}_{3}$ and $\mathrm{GaF}_{3} \cdot 3 \mathrm{H}_{2} \mathrm{O}$ precursors, respectively). ${ }^{[15]}$ With these thoughts in mind, two such examples in the literature caught our eye in the form of the monometallic complexes $\left[\mathrm{Mn}(\mathrm{III}) \mathrm{F}_{3}\left(\mathrm{H}_{2} \mathrm{O}\right)(\mathrm{L})\right] \cdot x \mathrm{H}_{2} \mathrm{O}\left(\mathrm{L}_{1}=2,2^{\prime}\right.$-Bipyridine, $x=0$ (1) or $\mathrm{L}_{2}=$ 1,10'-Phenanthroline, $x=1(2))$. These molecules were first synthesised as powders by Chaudhuri et $a^{[16]}$ and subsequently characterised crystallographically by the Núñez ${ }^{[17]}$ (1) and Rajasekharan ${ }^{[18]}$ (2) groups, respectively. Synthesis of these complexes involved the careful handling of toxic $48 \% \mathrm{HF}$ solutions, requiring manipulation in well ventilated areas. Drawing on our previous experience using anhydrous $\mathrm{MnF}_{3}$ as a precursor to larger polymetallic architectures, ${ }^{[19]}$ we herein report its utilisation in the synthesis of $\mathbf{1}^{\prime} \cdot 2 \mathrm{H}_{2} \mathrm{O}$ (the hydrated analogue of 1) and 2' (the dehydrated analogue of 2), using a facile reaction route which may be performed in just 5 minutes (Fig. 1). We also demonstrate the robust nature of this synthetic route by describing the formation of their siblings: $\left[\mathrm{MnF}_{3}\left(\mathrm{H}_{2} \mathrm{O}\right)\left(\mathrm{L}_{3}\right)\right](3)$, $\left[\mathrm{MnF}_{3}\left(\mathrm{H}_{2} \mathrm{O}\right)\left(\mathrm{L}_{4}\right)\right] \cdot 2 \mathrm{H}_{2} \mathrm{O}(4),\left[\mathrm{MnF}_{3}\left(\mathrm{H}_{2} \mathrm{O}\right)\left(\mathrm{L}_{5}\right)\right] \cdot 0.5 \mathrm{MeOH}$ (5) and 
$\left[\mathrm{MnF}_{3}\left(\mathrm{H}_{2} \mathrm{O}\right)\left(\mathrm{L}_{6}\right)\right] \quad(6) \quad\left(\mathrm{L}_{1}=2,2^{\prime}\right.$-Bipyridyl, $\mathrm{L}_{2}=1,10^{\prime}-$ Phenanthroline, $\mathrm{L}_{3}=6$-Methyl-2,2'-dipyridyl, $\mathrm{L}_{4}=4,4^{\prime}$-Dimethyl2,2'-dipyridyl, $L_{5}=5,5$ '-dimethyl-2,2'-dipyridyl and $L_{6}=5$-Chloro1,10-phenanthroline) (Fig. 2).

\section{Results and Discussion}

The monometallic complexes shown in Figures 1 and 2 were synthesised by heating a methanolic solution of $\mathrm{Mn}(\mathrm{III}) \mathrm{F}_{3}$ and the appropriate 1,2-diimine ligand $\left(L_{x}\right)$ at $50^{\circ} \mathrm{C}$ until a dark red / black colour had formed. Such heating is required to break down and dissolve the extended network structure of $\mathrm{MnF}_{3}$. Red / orange crystalline solids of 1'-6 subsequently precipitated slowly from the mother liquor, although slow $\mathrm{Et}_{2} \mathrm{O}$ diffusion also facilitates X-ray diffraction quality single crystal growth of all complexes. The structures of 1'-6 each comprise a single JahnTeller elongated distorted octahedral Mn(III) centre, chelated by a single heterocyclic 1,2-diimine ligand ' $\mathrm{L}_{x}$ ', while three terminal $\mathrm{F}^{-}$ions and $\mathrm{a} \mathrm{H}_{2} \mathrm{O}$ ligand complete their coordination geometries. The axial distortions in these systems are consistently observed in the form of elongated $\mathrm{Mn1}-\mathrm{N} 1$ and $\mathrm{Mn1}-\mathrm{O} 1$ bonds with distances ranging between 2.146 and $2.309 \AA$, while the shorter terminal $\mathrm{Mn}-\mathrm{F}$ bonds range from 1.805 to $1.884 \AA$ (Table 1). The remaining Mn1-N2 bond distances range from 2.060 (in 3) to $2.129 \AA$ (in 4). Full crystallographic data on all complexes can be found in Tables 2 and 3. a)

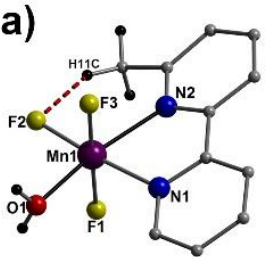

c)

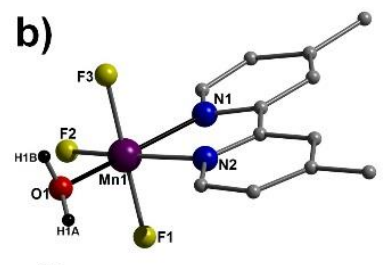

d)
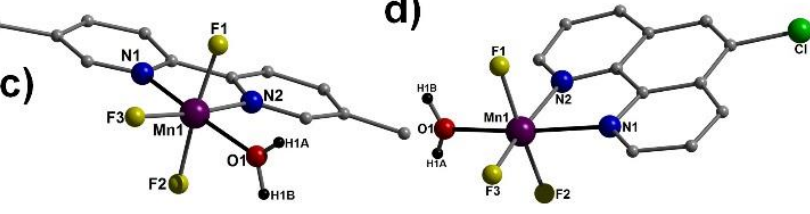

Figure 2. Crystal structures of complexes 3-6 (a-d), respectively. Colour code as used in Figure 1. Aromatic protons omitted for clarity. Intramolecular $\mathrm{H}$ bond distance in $\mathbf{3}$ given as dashed red line $(\mathrm{C} 11(\mathrm{H} 11 \mathrm{C}) \cdot \cdots \cdot \mathrm{F} 2=2.232 \AA)$.

The discrete moieties in 1'-3 each pack within their unit cells in a similar manner (Figure 3). The $\left[\mathrm{MnF}_{3}\left(\mathrm{H}_{2} \mathrm{O}\right)\left(\mathrm{L}_{x}\right)\right]$ units in each case arrange in superimposable stacks along the $b$ direction of their cells. These individual columns of monomeric units arrange along their ac planes in an interdigitated fashion with respect to their adjacent rows, forming close contacts primarily in the form of strong $\mathrm{H}$-bonding interactions between the terminal $\mathrm{F}^{-}$ligands and protons of juxtaposed terminal $\mathrm{H}_{2} \mathrm{O}$ ligands (e.g. $\mathrm{F} 1{ }^{\cdots} \mathrm{H}_{12}{ }^{\prime}\left(\mathrm{O} 1^{\prime}\right)=1.832 \AA$ in $1^{\prime} ; \mathrm{F}^{\prime}{ }^{\cdots} \mathrm{H}^{\prime} \mathrm{B}^{\prime}\left(\mathrm{O} 1^{\prime}\right)=1.878 \AA$ in $\mathbf{2}^{\prime}$,
$\mathrm{F} 1{ }^{\prime} \mathrm{H}_{1} \mathrm{H}^{\prime}\left(\mathrm{O} 1^{\prime}\right)=1.875 \AA$ in 3$)$, as well as via waters of crystallisation in the case of $1^{\prime}\left(\mathrm{F} 2 \cdots \mathrm{O} 2=2.732 \AA\right.$ and $\mathrm{F}^{\prime} \cdots \mathrm{O}^{\prime}{ }^{\prime}=$ $2.792 \AA$ ). Secondary interactions are also observed in the form of off-set $\pi_{\text {centroid }} \cdots \pi_{\text {centroid }}$ stacking interactions (e.g.[C1-N5] $\cdots\left[\mathrm{C}^{\prime}{ }^{\prime}-\right.$ $\mathrm{N}^{\prime}$ '] = $3.843 \AA$ in 1'; [C1-N1] $\cdots[\mathrm{C} 4-\mathrm{C} 12]=3.784 \AA$ in $\mathbf{2}^{\prime}$ and [C6$\mathrm{N} 2]^{\cdots}\left[\mathrm{C}^{\prime}-\mathrm{N} 2\right]=3.901 \AA$ in 3$)$. For a list of all intermolecular interactions in 1-6 and their corresponding distances see Table S1.

a)
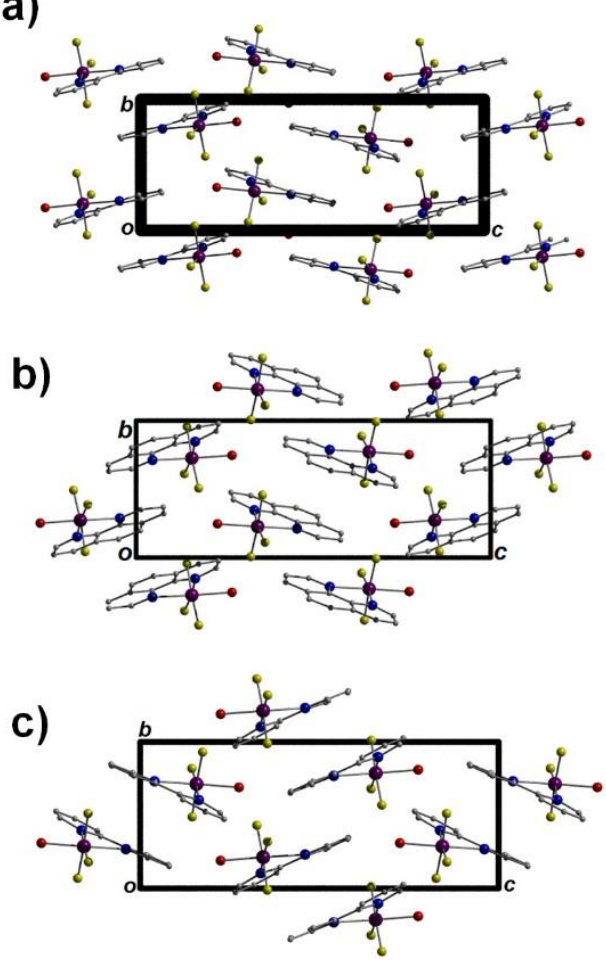

Figure 3. Packing arrays observed in 1' (a), 2' (b) and 3 (c) as viewed along the a direction of their unit cells. All hydrogen atoms and solvents of crystallisation (in $\mathbf{1}^{\prime}$ ) have been omitted for clarity. Colour code as used elsewhere in manuscript.

The $\{\mathrm{Mn}\}$ moieties in $\mathbf{4}$ are linked via multiple hydrogen bonding interactions concerning metal bound $\mathrm{F}^{-}$ligands with nearby $\mathrm{H}_{2} \mathrm{O}$ solvents of crystallisation (as in 1) and not with ligated $\mathrm{H}_{2} \mathrm{O}$ moieties as observed in $\mathbf{2}^{\prime}$ and $\mathbf{3}$ (see Table S1 for details). Offset $\pi_{\text {centroid }}{ }^{\prime} \pi_{\text {centroid }}$ arrangements are also forged along the a direction of the unit cell in $\mathbf{4}$ and are separated at a distance of $3.678 \AA \quad\left([\mathrm{C} 1-\mathrm{N} 1]^{\cdots}\left[\mathrm{C}^{\prime}{ }^{\prime}-\mathrm{N} 2{ }^{\prime}\right]\right) \quad$ (Fig. S1). The packing arrangements in $\mathbf{5}$ and $\mathbf{6}$ share similarities in that they both comprise superimposable columns of $\{\mathrm{Mn}\}$ units along the $b$ and a cell directions, respectively. More specifically these monomers arrange in brickwork sheets (propagating along the $a b$ planes in 5 and ac plane in 6) which are held in place by interdigitated offset $\pi_{\text {centroid }} \cdots \pi_{\text {centroid }}$ close contacts at distances of $3.886 \AA$ in $\mathbf{5}$ ([C7-N2] ' [C7'-N2']) and $3.681 \AA$ in 6 ([C1-N1] $\left.\cdots\left[C 1^{\prime}-N 1 '\right]\right)$. These $2 \mathrm{D}$ sheets align in parallel motifs across the ac plane in $\mathbf{5}$ and along the bc plane in $\mathbf{6}$ and are held in position via numerous $\mathrm{H}$ - 
bonding interactions between terminal $\mathrm{F}^{-}$ions and ligated water protons of juxtaposed monomers (e.g. $\mathrm{F}^{\cdots} \cdots \mathrm{H}^{1 \mathrm{~B}^{\prime}}\left(\mathrm{O} 1^{\prime}\right)=1.758 \AA$ in 5 and $\mathrm{F}{ }^{\cdots} \mathrm{H}_{1} \mathrm{~A}^{\prime}\left(\mathrm{O} 1^{\prime}\right)=1.766 \AA$ in 6$)$. Moreover, $\mathrm{Cl}{ }^{\cdots} \mathrm{F}$ dipoledipole interactions also influence the overall packing in 6 ( $\mathrm{F} 3 \cdots \mathrm{Cl} 1^{\prime}=2.874 \AA$ ) and leads to the slight packing differences observed between the two complexes (Fig. S1).

Table 1. Angles and distances concerning the J-T elongation axes in 1'-6.

\begin{tabular}{|c|c|c|}
\hline Complex & 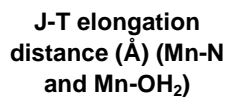 & $\begin{array}{c}\mathrm{J}-\mathrm{T} \text { elongation } \\
\text { angle }\left(^{\circ}\right) \\
(\mathrm{O}-\mathrm{Mn}-\mathrm{N})\end{array}$ \\
\hline$\left[\mathrm{MnF}_{3}\left(\mathrm{H}_{2} \mathrm{O}\right)\left(\mathrm{L}_{1}\right)\right] \cdot 2 \mathrm{H}_{2} \mathrm{O}\left(\mathbf{1}^{\prime}\right)$ & $2.220(2) ; 2.176(2)$ & 168.95 \\
\hline$\left[\mathrm{MnF}_{3}\left(\mathrm{H}_{2} \mathrm{O}\right)\left(\mathrm{L}_{2}\right)\right]\left(2^{\prime}\right)$ & $2.261(2) ; 2.166(2)$ & 166.99 \\
\hline$\left[\mathrm{MnF}_{3}\left(\mathrm{H}_{2} \mathrm{O}\right)\left(\mathrm{L}_{3}\right)\right](3)$ & $2.309(2) ; 2.194(2)$ & 164.92 \\
\hline$\left[\mathrm{MnF}_{3}\left(\mathrm{H}_{2} \mathrm{O}\right)\left(\mathrm{L}_{4}\right)\right] \cdot 2 \mathrm{H}_{2} \mathrm{O}(\mathbf{4})$ & $2.216(8), 2.146(7)$ & 166.67 \\
\hline $\begin{array}{c}{\left[\mathrm{MnF}_{3}\left(\mathrm{H}_{2} \mathrm{O}\right)\left(\mathrm{L}_{5}\right)\right] \cdot 0.5 \mathrm{MeOH}} \\
(\mathbf{5})\end{array}$ & $2.246(3) ; 2.171(3)$ & 168.60 \\
\hline$\left[\mathrm{MnF}_{3}\left(\mathrm{H}_{2} \mathrm{O}\right)\left(\mathrm{L}_{6}\right)\right](\mathbf{6})$ & $2.260(7) ; 2.153(7)$ & 167.25 \\
\hline
\end{tabular}

Table $2 \mathrm{X}$-ray crystallographic data obtained from complexes $1^{\prime}-4$

\begin{tabular}{|c|c|c|c|c|}
\hline & $1^{\prime} 2 \mathrm{H}_{2} \mathrm{O}$ & $2^{\prime}$ & 3 & $4 \cdot 2 \mathrm{H}_{2} \mathrm{O}$ \\
\hline Formula $^{a}$ & $\begin{array}{c}\mathrm{C}_{10} \mathrm{H}_{14} \mathrm{~N}_{2} \mathrm{O}_{3} \\
\mathrm{~F}_{3} \mathrm{Mn}_{1}\end{array}$ & $\begin{array}{c}\mathrm{C}_{12} \mathrm{H}_{10} \mathrm{~N}_{2} \mathrm{O}_{1} \\
\mathrm{~F}_{3} \mathrm{Mn}_{1}\end{array}$ & $\begin{array}{c}\mathrm{C}_{11} \mathrm{H}_{12} \mathrm{~N}_{2} \mathrm{O}_{1} \\
\mathrm{~F}_{3} \mathrm{Mn}_{1}\end{array}$ & $\begin{array}{c}\mathrm{C}_{12} \mathrm{H}_{14} \mathrm{~N}_{2} \mathrm{O}_{3} \mathrm{~F}_{3} \\
\mathrm{Mn}_{1}\end{array}$ \\
\hline$M_{W}$ & 322.17 & 310.16 & 300.17 & 346.19 \\
\hline $\begin{array}{l}\text { Crystal } \\
\text { System }\end{array}$ & Monoclinic & Monoclinic & Monoclinic & Triclinic \\
\hline $\begin{array}{l}\text { Space } \\
\text { group }\end{array}$ & $\mathrm{P} 2_{1} / \mathrm{n}$ & $\mathrm{P} 2_{1} / \mathrm{c}$ & $\mathrm{P} 2_{1} / \mathrm{c}$ & $P-1$ \\
\hline$a / \AA ̊ A$ & $9.0453(2)$ & $8.3759(17)$ & $8.3482(4)$ & $6.8782(5)$ \\
\hline$b / A ̊$ & $7.4043(2)$ & $7.2941(15)$ & $7.4997(3)$ & $10.3111(14)$ \\
\hline$c / \AA ̊ A$ & $19.4455(4)$ & $19.268(4)$ & $18.7579(10)$ & $10.6165(19)$ \\
\hline$\alpha /^{\circ}$ & 90 & 90 & 90 & $73.723(15)$ \\
\hline$\beta /^{\circ}$ & $95.425(2)$ & $101.83(3)$ & $102.664(4)$ & $86.860(12)$ \\
\hline$\gamma^{\circ}$ & 90 & 90 & 90 & $85.570(9)$ \\
\hline$V / A^{3}$ & $1296.51(5)$ & $1152.2(4)$ & $1145.84(10)$ & $720.17(17)$ \\
\hline$z$ & 4 & 4 & 4 & 2 \\
\hline$T / K$ & $150(2)$ & $150(2)$ & $150(2)$ & $150(2)$ \\
\hline$\lambda^{\mathrm{D} / \mathrm{A}}$ & 0.71073 & 0.71073 & 0.71073 & 0.71073 \\
\hline$D_{d} / \mathrm{g} \mathrm{cm}^{-3}$ & 1.651 & 1.788 & 1.740 & 1.596 \\
\hline $\begin{array}{c}\mu(\mathrm{Mo}-\mathrm{Ka}) / \\
\mathrm{mm}^{-1}\end{array}$ & 1.060 & 1.177 & 1.180 & 0.960 \\
\hline Meas./indep & $3156 / 2390$ & $2105 / 1840$ & 2089/1933 & 2649/2065(0. \\
\hline
\end{tabular}

\begin{tabular}{|c|c|c|c|c|}
\hline . $\left(R_{\text {int }}\right)$ refl. & $(0.0633)$ & $(0.0287)$ & $(0.0195)$ & 0534) \\
\hline $\begin{array}{l}\text { Restraints, } \\
\text { Parameters }\end{array}$ & 9,196 & 0,180 & 0,172 & 0,196 \\
\hline $\begin{array}{c}\text { wR2 (all } \\
\text { data) }\end{array}$ & 0.0879 & 0.0931 & 0.0585 & 0.3463 \\
\hline$R 1^{d, e}$ & 0.0564 & 0.0360 & 0.0221 & 0.1208 \\
\hline $\begin{array}{l}\text { Goodness } \\
\text { of fit on } F^{2}\end{array}$ & 1.047 & 1.082 & 1.075 & 1.116 \\
\hline
\end{tabular}

Table 3. X-ray crystallographic data obtained from complexes 5 and $\mathbf{6 .}$

\begin{tabular}{|c|c|c|}
\hline & $5 \cdot 0.5 \mathrm{MeOH}$ & 6 \\
\hline Formula $^{a}$ & $\mathrm{C}_{12.5} \mathrm{H}_{14.5} \mathrm{~N}_{2} \mathrm{O}_{1.5} \mathrm{~F}_{3} \mathrm{Mn}_{1}$ & $\mathrm{C}_{12} \mathrm{H}_{9} \mathrm{~N}_{2} \mathrm{O}_{1} \mathrm{Cl}_{1} \mathrm{~F}_{3} \mathrm{Mn}_{1}$ \\
\hline$M_{W}$ & 328.70 & 344.60 \\
\hline Crystal System & Monoclinic & Orthorhombic \\
\hline Space group & $12 / a$ & Pbca \\
\hline$a / \AA$ & $16.4291(7)$ & $7.3151(5)$ \\
\hline$b / A ̆$ & $7.6236(4)$ & $16.5375(14)$ \\
\hline$c / A ̈$ & $23.0374(14)$ & $20.773(2)$ \\
\hline$\alpha /^{\circ}$ & 90 & 90 \\
\hline$\beta /^{\circ}$ & $102.176(5)$ & 90 \\
\hline$y /^{\circ}$ & 90 & 90 \\
\hline$V / \AA^{3}$ & $2820.5(3)$ & $2513.0(4)$ \\
\hline$Z$ & 8 & 8 \\
\hline$T / \mathrm{K}$ & $150(2)$ & $150(2)$ \\
\hline$\lambda^{\mathrm{b}} / \mathrm{A}$ & 0.71073 & 0.71073 \\
\hline$D_{\mathrm{c}} / \mathrm{g} \mathrm{cm}^{-3}$ & 1.548 & 1.822 \\
\hline$\mu(\mathrm{Mo}-\mathrm{Ka}) / \mathrm{mm}^{-1}$ & 0.969 & 1.295 \\
\hline
\end{tabular}

Meas./indep. $\left(R_{\text {int }}\right)$ refl.

$2573 / 2226(0.03233)$

$2297 / 1224(0.2124)$

\begin{tabular}{|c|c|c|}
\hline $\begin{array}{l}\text { Restraints, } \\
\text { Parameters }\end{array}$ & 0,189 & 0,186 \\
\hline wR2 (all data) & 0.1108 & 0.2065 \\
\hline$R 1^{a, e}$ & 0.0453 & 0.0812 \\
\hline Goodness of fit on $F^{2}$ & 1.183 & 1.042 \\
\hline \multicolumn{3}{|c|}{$\begin{array}{l}{ }^{a} \text { Includes guest molecules. }{ }^{b} \text { Mo-Ka radiation, graphite monochromator. }{ }^{c} \\
w R 2=\left[\Sigma w\left(\left|F_{0}^{2}\right|-\left|F_{\mathrm{c}}^{2}\right|\right)^{2} / \Sigma w\left|F_{0}^{2}\right|^{2}\right]^{1 / 2} \text {. }{ }^{d} \text { For observed data. }{ }^{e} R 1=\Sigma \|\left|F_{0}\right|-\left|F_{\mathrm{c}}\right| l / \\
\Sigma\left|F_{0}\right| .\end{array}$} \\
\hline
\end{tabular}

\section{Magnetic susceptibility measurements}

Dc magnetic susceptibility measurements were performed on powdered microcrystalline samples of 1'-6 in an applied magnetic field of $0.1 \mathrm{~T}$ and in the temperature range 300 to $5 \mathrm{~K}$. The results are plotted as the $X_{\mathrm{M}} T$ products versus $T$ in the 
insets of Figure 4 and Figures S3 and S4. The high temperature $X_{\mathrm{M}} T$ values obtained range from 2.84 (in 2 ) to 3.29 (in 3 ) $\mathrm{cm}^{3} \mathrm{~K}$ $\mathrm{mol}^{-1}$ and are very close to that expected $\left(3.00 \mathrm{~cm}^{3} \mathrm{~K} \mathrm{~mol}^{-1}\right.$ for $\mathrm{g}$ $=2.00)$ for a single, high-spin, $d^{4} \mathrm{Mn}(\mathrm{III})$ ion. The values decrease gradually before dropping more rapidly at lower temperatures $(\sim 10 \mathrm{~K})$. This behaviour can be assigned to the combination of extensive [and rather complicated] intermolecular interactions observed in the crystal structures of 1'-6 and zerofield splitting effects. The $T=5 \mathrm{~K} \chi_{M} T$ products all lie in the range $1.94\left(\mathbf{2}^{\prime}\right)$ to $2.57(\mathbf{5}) \mathrm{cm}^{3} \mathrm{~K} \mathrm{~mol}^{-1}$, somewhat lower than that expected from an isolated, isotropic $S=2$ ion $\left(3.00 \mathrm{~cm}^{3} \mathrm{~K}\right.$ $\left.\mathrm{mol}^{-1}, g=2.00\right)$. In order to determine the single-ion axial anisotropy parameter for the $\mathrm{Mn}(\mathrm{III})$ centres in 1'-6 variabletemperature-variable-field dc magnetisation $(M)$ experiments were performed in the $2.0-7.0 \mathrm{~K}$ and $0.5-7.0 \mathrm{~T}$ temperature and magnetic field ranges. The experimental data are presented in Figures 4, S3 and S4. The data were numerically fitted by use of the simplex algorithm ${ }^{[20]}$ to the spin-Hamiltonian below, by numerical diagonalisation of the full spin-Hamiltonian matrix.

$$
\hat{H}=\sum_{i=1}\left\{\mu_{B} \vec{B} g \hat{S}_{i}+D\left[\hat{S}_{z, i}^{2}-S_{i}\left(S_{i}+1\right) / 3\right]\right\}
$$

Here, $D$ is the uniaxial anisotropy and $S_{\mathrm{Mn}(\mathrm{III})}=2$ the total spin of the $\mathrm{Mn}(\mathrm{III})$ ion. The best fit $D_{\mathrm{Mn}(\mathrm{III})}$ parameters were $\left(\mathrm{cm}^{-1}\right):-3.97$ (1'), -3.01 (2'), -3.10 (3), -3.90 (4), -4.02 (5) and -3.97 (6) (Table 3). These ZFS parameters were then employed to fit the corresponding magnetic susceptibility data, which also required use of a mean field term $\left(z J^{\prime}\right)$ affording values of $-0.55 \mathrm{~K}\left(\mathbf{1}^{\prime}\right)$; $1.33 \mathrm{~K}\left(\mathbf{2}^{\prime}\right) ;-1.00 \mathrm{~K}(3) ;-0.25 \mathrm{~K}(4) ;+0.07 \mathrm{~K}(5) ;-1.11 \mathrm{~K}(6)$.
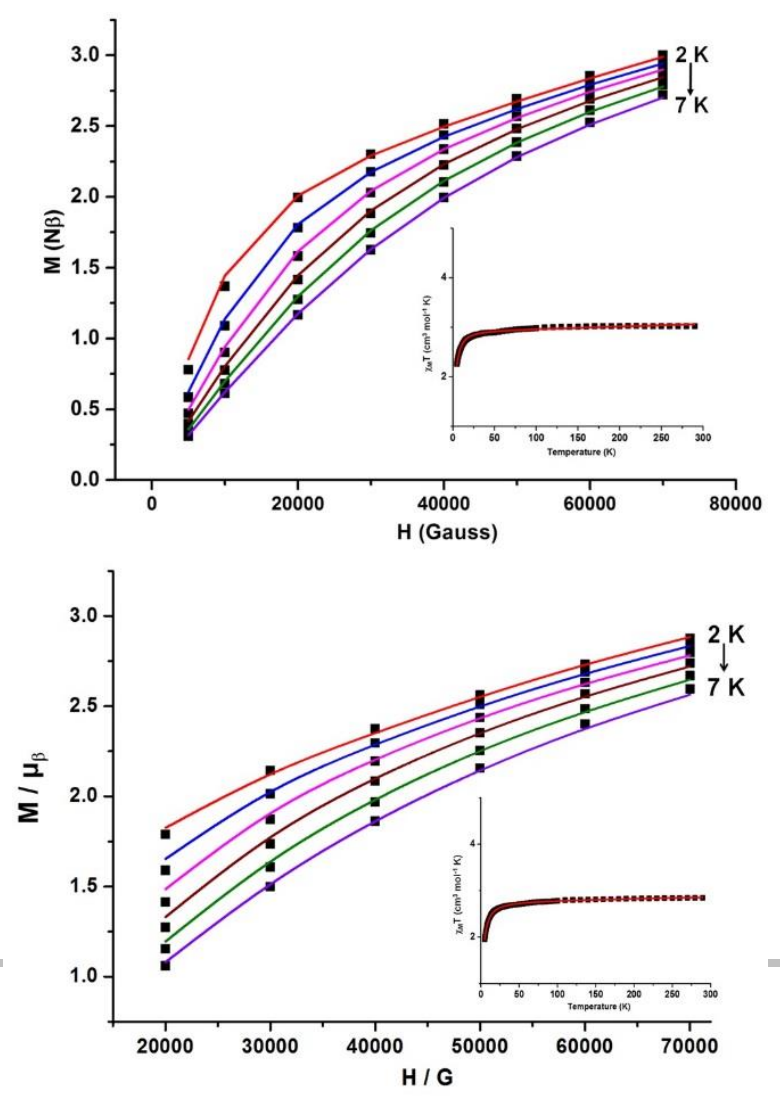

Figure 4. Plots of magnetisation $\left(M / \mu_{\mathrm{B}}\right)$ versus Field $(H / \mathrm{G})$ and (insets) magnetic susceptibility $\left(\chi_{\mathrm{M}} T / \mathrm{cm}^{3} \mathrm{~K} \mathrm{~mol}^{-1}\right)$ versus temperature $(\mathrm{T} / \mathrm{K})$ obtained from polycrystalline samples of 1' (top) and 2' (bottom). The solid lines represent the best-fit to the data. See main text and Table 4 for details.

\section{MF / HF-EPR Spectroscopy}

The magnitude of the $D$ tensor obtained for 1'-6 each lie on the upper limit of standard W-band spectrometers and so multifrequency / high field EPR was employed here. Powdered and pelletised samples of 1', 2', 4 and 5 were measured at several frequencies ranging from $220 \mathrm{GHz}$ to $575 \mathrm{GHz}$ and at both 15 and $5 \mathrm{~K}$ (Figures 5-7 and S5-8). In all spectra, a signal at $g=2$ (at $7.9 \mathrm{~T}$ for $220.8 \mathrm{GHz}$ and $11.8 \mathrm{~T}$ at $331.2 \mathrm{GHz}$ ) is observed with an increasing intensity as the temperature is increased and is tentatively assigned to a $\mathrm{Mn}$ (II) impurity. For all frequencies, several signals are recorded whose intensities change markedly with temperature. All spectra exhibit complicated fine structure, as expected for complexes with uniaxial anisotropies of several wavenumbers, which forbid any simple preliminary analysis. Satisfactory simulations of the spectra were obtained for all four complexes giving rise to the following sets of parameters: $D=$ $4.25(3) \mathrm{cm}^{-1}, E=0.49(3) \mathrm{cm}^{-1}, g_{\mathrm{x}}=g_{\mathrm{y}}=1.99(6)$ and $g_{\mathrm{z}}=2.00(5)$ (1'); $D=-4.03(5) \mathrm{cm}^{-1}, E=0.18(2) \mathrm{cm}^{-1}, g_{\mathrm{x}}=g_{\mathrm{y}}=1.96(5)$ and $g_{\mathrm{z}}=$ $1.98(4)\left(2^{\prime}\right) ; D=-3.90(3) \mathrm{cm}^{-1}, E=1.20(2) \mathrm{cm}^{-1}, g_{\mathrm{x}}=g_{\mathrm{y}}=1.98(6)$ and $g_{\mathrm{z}}=2.00(5)(4)$ and $D=-4.04(6) \mathrm{cm}^{-1}, E=0.22(3) \mathrm{cm}^{-1}, g_{\mathrm{x}}=$ $g_{y}=2.00(7)$ and $g_{z}=2.00(6)(5)$; which are comparable to those obtained from magnetisation measurements (Table 4). It should be noted here that accuracy in ascertaining $g$-values is severely hampered due to the masking effect of the large $|D|$ terms associated with each complex. As shown in Figures 5-7 (and S5-S8), the resonance positions in the experimental spectra are rather well reproduced in comparison to their corresponding simulated spectra, however their relative intensities within each spectrum are less satisfactorily reproduced. This less than ideal intensity reproduction is likely attributed to commonly observed torqueing effects; that are minimised (although not eradicated) through sample pelletisation, as is the case in this work. 
For all complexes, the $z$ component of their $M=-2 \rightarrow-1$ transition are observed in the spectra recorded at the highest frequencies; corresponding to an intense feature close to $3.5 \mathrm{~T}$ (at $460 \mathrm{GHz}$ ) and $7.5 \mathrm{~T}$ (at $575 \mathrm{GHz}$ ) at $5 \mathrm{~K}$, whose intensity decreases when the temperature is increased. Similarly, at $220.8 \mathrm{GHz}$, the $x$ and $y$ components of the $\mathrm{M}=-2 \rightarrow-1$ transition are clearly observed in the high field part of the spectra, with the same temperature behaviour. More specifically, the $y$ component appears close to $13.5 \mathrm{~T}$ for complexes 1', 2' and $\mathbf{5}$ (Fig. 5 and S7) and at $9.3 \mathrm{~T}$ for the more rhombic complex 4 (Fig 7 ). The $x$ component is observed only for complexes 2 ' and 5 at 15.5 and $15.3 \mathrm{~T}$ respectively. For complexes $\mathbf{1}^{\prime}$ and $\mathbf{4}$ this resonance is expected at fields lying outside the range of our superconducting magnet (> 16 T). For all complexes except 2' (where the S/N does not allow confident assignment), signals associated with the $\mathrm{M}=-1 \rightarrow 0$ transition are also observed, especially in the spectra recorded at $331.2 \mathrm{GHz}$. The $\mathrm{z}$ component is found at $8.7 \mathrm{~T}\left(\mathbf{1}^{\prime}\right.$ and 5 ) or 9.2 T (4), while the $x$ component resonated close to $12 \mathrm{~T}$ for both $\mathbf{1}^{\prime}$ and $\mathbf{5}$ and at 14.6 $\mathrm{T}$ for 4 . The corresponding $y$ component signals are observed at 9.3 $\mathrm{T}\left(\mathbf{1}^{\prime}\right)$, 8.8 $\mathrm{T}(\mathbf{4})$ and $10.4 \mathrm{~T}(\mathbf{5})$. The other recurrent features associated with allowed transitions are the $x$ and $y$ components of the $\mathrm{M}=0 \rightarrow+1$ transition. For instance at $460 \mathrm{GHz}$, the $x$ component is found at $13.0 \mathrm{~T}\left(\mathbf{1}^{\prime}\right), 13.7 \mathrm{~T}\left(\mathbf{2}^{\prime}\right), 12.6 \mathrm{~T}(\mathbf{4})$ and 13.2 T (5), whereas the $y$ component is found at $13.6 \mathrm{~T}$ ( 1 ' and 5), $13.9 \mathrm{~T}\left(\mathbf{2}^{\prime}\right)$ and $14.1 \mathrm{~T}$ (4). As shown in Figures 6, 7 and S7, the close to zero field signal observed in the $331.2 \mathrm{GHz}$ spectra of 1', 2' and $\mathbf{5}$ are assigned to the $z$ component of the 'forbidden' transition $\mathrm{M}_{\mathrm{ZFS}}=+2 \rightarrow-1$ (using the ZFS labelling of the energy levels). Such a signal is absent for complex 4 , where a quasirhombic $(|E / D| \sim 0.31)$ energy diagram holds.
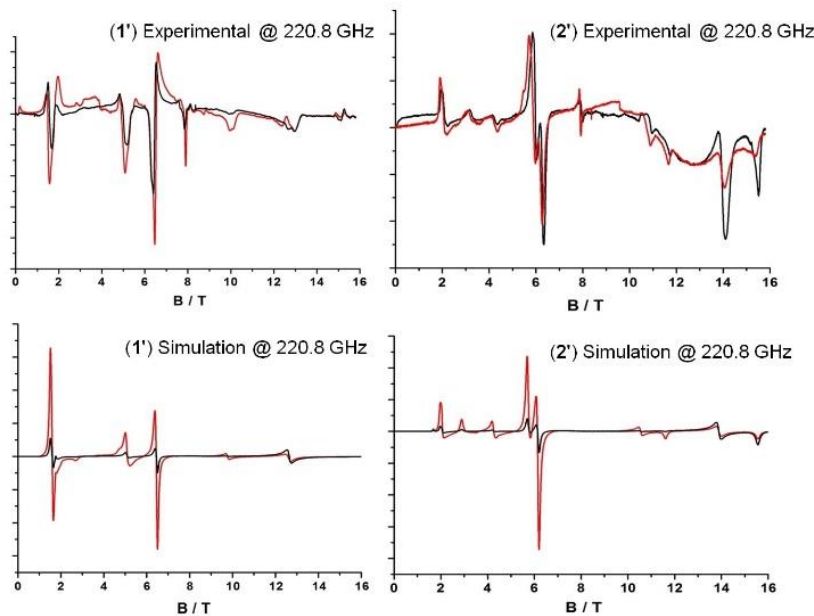

Figure 5. Experimental and simulated MF / HF-EPR spectra obtained on polycrystalline sample pellets of $\left[\mathrm{MnF}_{3}\left(\mathrm{H}_{2} \mathrm{O}\right)\left(\mathrm{L}_{1}\right)\right] \cdot 2 \mathrm{H}_{2} \mathrm{O} \quad\left(\mathbf{1}^{\prime}\right)$ and $\left[\mathrm{MnF}_{3}\left(\mathrm{H}_{2} \mathrm{O}\right)\left(\mathrm{L}_{1}\right)\right]\left(2^{\prime}\right)$, carried out and simulated at a frequency of $220.8 \mathrm{GHz}$ and temperatures of $15 \mathrm{~K}$ (red line) and $5 \mathrm{~K}$ (black line).
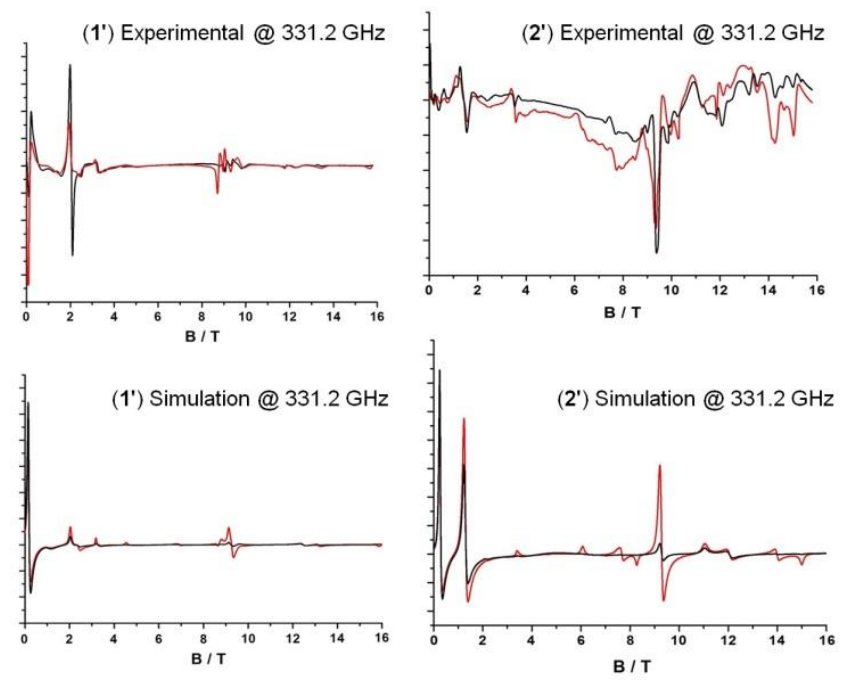

Figure 6. Experimental and simulated MF / HF-EPR spectra obtained on polycrystalline sample pellets of $\left[\mathrm{MnF}_{3}\left(\mathrm{H}_{2} \mathrm{O}\right)\left(\mathrm{L}_{1}\right)\right] \cdot 2 \mathrm{H}_{2} \mathrm{O} \quad\left(\mathbf{1}^{\prime}\right)$ and $\left[\mathrm{MnF}_{3}\left(\mathrm{H}_{2} \mathrm{O}\right)\left(\mathrm{L}_{1}\right)\right]\left(2^{\prime}\right)$, carried out and simulated at a frequency of $331.2 \mathrm{GHz}$ and temperatures of $15 \mathrm{~K}$ (red line) and $5 \mathrm{~K}$ (black line).
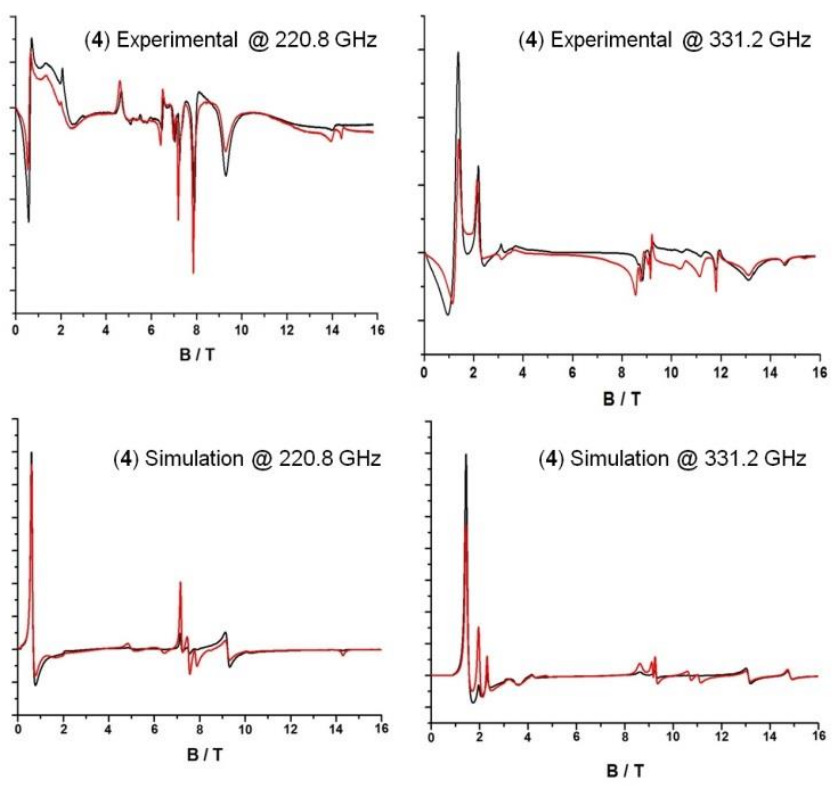

Figure 7. Experimental and simulated MF / HF-EPR spectra obtained on a polycrystalline sample pellets of $\left[\mathrm{MnF}_{3}\left(\mathrm{H}_{2} \mathrm{O}\right)\left(\mathrm{L}_{4}\right)\right] \cdot 2 \mathrm{H}_{2} \mathrm{O}(4)$, carried out and simulated at frequencies of 220.8 and $331.2 \mathrm{GHz}$ respectively and temperatures of $15 \mathrm{~K}$ (red line) and $5 \mathrm{~K}$ (black line). 
Table 4. Anisotropic magnetic parameters obtained from 1'-6 using magnetisation versus field (M vs $H$ ) and MF / HF-EPR measurements. Key: - = not measured.

\begin{tabular}{|c|c|c|c|c|c|c|c|}
\hline \multicolumn{3}{|c|}{ M vs $\mathrm{H}$ studies } & \multicolumn{5}{|c|}{ MF / HF-EPR studies } \\
\hline Complex & g-value & $D\left(\mathrm{~cm}^{-1}\right)$ & $g_{x}$ & $g_{y}$ & $g_{z}$ & $D\left(\mathrm{~cm}^{-1}\right)$ & $E\left(\mathrm{~cm}^{-1}\right)$ \\
\hline$\left[\mathrm{MnF}_{3}\left(\mathrm{H}_{2} \mathrm{O}\right)\left(\mathrm{L}_{1}\right)\right] \cdot 2 \mathrm{H}_{2} \mathrm{O}\left(\mathbf{1}^{\prime}\right)$ & 2.0 & -3.97 & $1.99(6)$ & $1.99(6)$ & $2.00(5)$ & $-4.25(3)$ & $0.49(3)$ \\
\hline$\left[\mathrm{MnF}_{3}\left(\mathrm{H}_{2} \mathrm{O}\right)\left(\mathrm{L}_{2}\right)\right]\left(\mathbf{2}^{\prime}\right)$ & 2.0 & -3.01 & $1.96(5)$ & $1.96(5)$ & $1.98(4)$ & $-4.03(5)$ & $0.18(2)$ \\
\hline$\left[\mathrm{MnF}_{3}\left(\mathrm{H}_{2} \mathrm{O}\right)\left(\mathrm{L}_{3}\right)\right](3)$ & 2.0 & -3.10 & - & - & - & - & - \\
\hline$\left[\mathrm{MnF}_{3}\left(\mathrm{H}_{2} \mathrm{O}\right)\left(\mathrm{L}_{4}\right)\right] \cdot 2 \mathrm{H}_{2} \mathrm{O}(\mathbf{4})$ & 2.0 & -3.90 & $1.98(6)$ & $1.98(6)$ & $2.00(5)$ & $-3.90(3)$ & $1.20(2)$ \\
\hline$\left[\mathrm{MnF}_{3}\left(\mathrm{H}_{2} \mathrm{O}\right)\left(\mathrm{L}_{5}\right)\right] \cdot 0.5 \mathrm{MeOH}(5)$ & 2.0 & -4.02 & $2.00(7)$ & $2.00(7)$ & $2.00)(6)$ & $-4.04(6)$ & $0.22(3)$ \\
\hline$\left[\mathrm{MnF}_{3}\left(\mathrm{H}_{2} \mathrm{O}\right)\left(\mathrm{L}_{6}\right)\right](6)$ & 2.0 & -3.97 & - & - & - & - & - \\
\hline
\end{tabular}


Complexes 1'-6 add to a $600+$ long list of reported monomeric $\mathrm{Mn}$ (III) complexes although only a small percentage $(\sim 5 \%)$ of these publications come with significant magnetic elucidation. For convenience, these complexes along with their various spin Hamiltonian parameters (i.e. $g, D$ and $E$ tensors) are given in Table S6. The spin Hamiltonian data extracted here are comparable to literature values, including the structurally related complex $\left[\mathrm{Mn}(\mathrm{III}) \mathrm{F}_{3}\right.$ (terpy) $\left(D=-3.82 \mathrm{~cm}^{-1}, E=0.75 \mathrm{~cm}^{-1}, g_{x}=\right.$ $1.97(2), g_{y}=2.04(1)$ and $\left.g_{z}=1.96(1)\right)$; where terpy $=2,2^{\prime}: 6^{\prime}, 2^{\prime \prime}-$ terpyridine (see Table S6 for more information). ${ }^{[1]}$ The simulation of complex 4 requires a significantly larger rhombic term $\left(E=1.20(2) \mathrm{cm}^{-1}\right.$ ) when compared to its siblings (ranging from $0.18(2) \mathrm{cm}^{-1}$ (in 2') to 0.49 (3) in 1') and may be attributed to its lower symmetry highlighted by its less pronounded axial elongation, with distances of Mn1-N1 (2.216(8)) and Mn1-O1 (2.146(7)) when compared to $1^{\prime}(\mathrm{Mn} 1-\mathrm{N} 1=2.220(2), \mathrm{Mn} 1-\mathrm{O} 1=$ 2.176(2)), 2' ((Mn1-N1 = 2.261(2), Mn1-O1 = 2.166(2)) and 5 $(\mathrm{Mn} 1-\mathrm{N} 1=2.246(3), \mathrm{Mn} 1-\mathrm{O} 1=2.171(3))$ (see Table 1$)$. Another contributing factor may be the lower symmetry crystallisation of 4 (triclinic, $P$-1) when compared to complexes $\mathbf{1}^{\prime}$ and $\mathbf{2}^{\prime}$ (monoclinic $P 2_{1} / \mathrm{n}$ and $P 2_{1} / \mathrm{c}$ respectively), although it should be noted that complex $\mathbf{5}$ also crystallises in a monoclinic space group (I/2/a).

\section{Raman Studies}

Solid state Raman spectra were obtained from $1.5 \% \mathrm{w} / \mathrm{w}$ dispersions in $\mathrm{KBr}$ solid matrices of complexes 1'-6, ligands $L_{1}$ $\mathrm{L}_{6}$ and $\mathrm{MnF}_{3}$ as purchased (see experimental section for details), while FT-IR spectra were also obtained from polycrystalline samples of 1'-6. All data were normalised and baseline corrected using standard methods unless otherwise stated. The experimental Raman spectrum of $\mathrm{MnF}_{3}$ deviates from the published literature values $\left(283,513\right.$ and $651 \mathrm{~cm}^{-1}$ in ref. [22] and 530, 619 and $655 \mathrm{~cm}^{-1}$ in ref. [23]). The peaks at 655 (and $651 \mathrm{~cm}^{-1}$ ) and at 619 and $530 \mathrm{~cm}^{-1}$ were tentatively attributed to $\mathrm{Mn}-\mathrm{F}$ and $\mathrm{Mn}-\mathrm{F}-\mathrm{Mn}$ bridge stretching modes, respectively. ${ }^{[23]}$ When the $\mathrm{MnF}_{3} / \mathrm{KBr}$ matrix was prepared in this work the spectrum obtained exhibits prominent peaks at 262 (broad), 420-491 (a set of six bands), a strong peak at 574 with a shoulder at 595(sh) and a peak at $625 \mathrm{~cm}^{-1}$ (Fig. S10). We attribute these differences to the hygroscopic nature of the $\mathrm{MnF}_{3}$ starting material, leading to the formation of the $\mathrm{MnF}_{3} \cdot 3 \mathrm{H}_{2} \mathrm{O}$ hydrate (of which there are two polymorphs). ${ }^{[24]}$ Indeed, peaks in the $300-400 \mathrm{~cm}^{-1}$ region of our $\mathrm{MnF}_{3}$ spectrum correspond to $\mathrm{Mn}-\mathrm{OH}_{2}$ stretches as observed in the literature. ${ }^{[25]}$

The weak band at $625 \mathrm{~cm}^{-1}$ is attributed to $\mathrm{MnF}_{3}$, however since it is $\sim 1 / 3^{\text {rd }}$ as intense as the $574 \mathrm{~cm}^{-1}$ band (which can be attributed to the terminal $\mathrm{Mn}-\mathrm{F}$ stretching of the various octahedral $\mathrm{Mn}$ (III) species), it means that it is present in low concentration. The $491 \mathrm{~cm}^{-1}$ band is assigned to the Mn-F-Mn bridge stretching mode. The Raman spectra of 1'-6 corroborate these findings with each sample exhibiting peaks in these regions (i.e. 244, 481 and $582 \mathrm{~cm}^{-1}$ in $1^{\prime}$ and $276,482,574 \mathrm{~cm}^{-1}$ in $2^{\prime}$ ) (Figures 8, 9, S10 and S14). Since rigorous moisture control was not implemented during storage of the anhydrous $\mathrm{MnF}_{3}$, we cannot be certain which octahedral species are present in the $\mathrm{MnF}_{3}$ starting material. Acquisition of the Raman spectra of pure anhydrous $\mathrm{MnF}_{3}$ by this $\mathrm{KBr}$ disc method would have required a much more arduous procedure, which was not necessary here, it was more important to look at the starting material as used during the synthesis of $\mathbf{1}^{\prime}-6$. Moreover, the $\mathrm{KBr}$ method was necessary for these darkly coloured complexes as many were burnt due to excessive absorption of excitation light; a common problem with coloured compounds during Raman analysis.

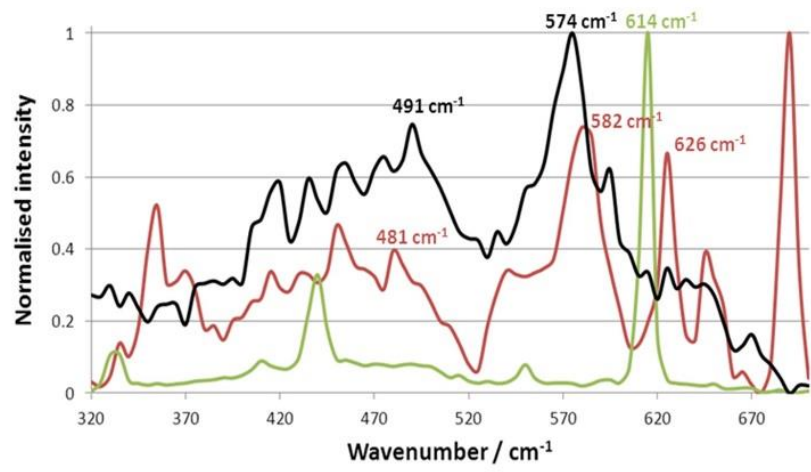

Figure 8. Raman spectra in the $320-700 \mathrm{~cm}^{-1}$ region obtained from a crystalline sample of $\left[\mathrm{Mn}(\mathrm{III}) \mathrm{F}_{3}\left(\mathrm{H}_{2} \mathrm{O}\right)\left(\mathrm{L}_{1}\right)\right] \cdot 2 \mathrm{H}_{2} \mathrm{O}$ (1') (red line), 2,2'-bipyridyl (green line) and a $\mathrm{MnF}_{3} \cdot 3 \mathrm{H}_{2} \mathrm{O} / \mathrm{KBr}$ mixture (black line).

Similarities between the Raman spectra of 1' and 2,2'-Bipyridyl $\left(L_{1}\right)$ can be seen in Figures 8, S9 and $S 12$ and pertinent bands are also tabulated in Tables S2 and S3. Castellucci and coworkers made reliable assignments of the internal Raman modes of 2,2'-bipyridyl and designated peaks at 616, 1056 and $1308 \mathrm{~cm}^{-1}$ to an in-plane ring deformation, ring-ring stretching and a $\mathrm{C}-\mathrm{H}$ deformation respectively, ${ }^{[26]}$ while other research groups have described similar results. ${ }^{[27],[28]}$ These figures compare well with our experimental figures of 614, 1046 and $1301 \mathrm{~cm}^{-1}$ for 2,2'-bipyridyl. Related peaks are present in the spectrum of complex $\mathbf{1}^{\prime}$ at 626,1059 and $1311 \mathrm{~cm}^{-1}$. Likewise, Figure 9 highlights the similarities between the Raman spectra of $2^{\prime}$ and $1,10^{\prime}$-phenanthroline $\left(L_{2}\right)$. More specifically, peaks at $410,710,1035,1295,1406$ and $1445 \mathrm{~cm}^{-1}$ are the most intense bands observed in the Raman spectrum of $L_{2}$, which correlate with literature values as shown in Table S4. These bands are due to in-plane modes $\left(A_{1}\right){ }^{[29],[30]}$ 


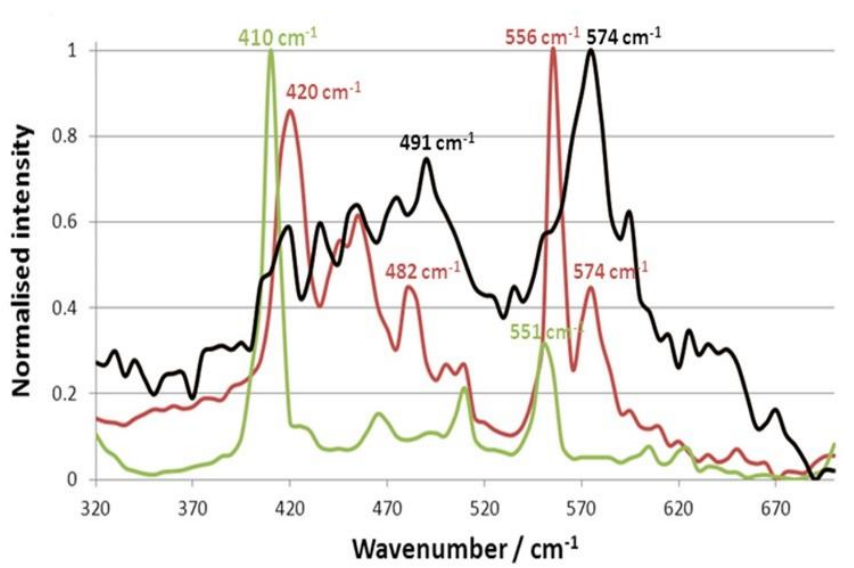

Figure 9. Raman spectra in the $320-700 \mathrm{~cm}^{-1}$ region obtained from a crystalline sample of $\left[\mathrm{Mn}(\mathrm{III}) \mathrm{F}_{3}\left(\mathrm{H}_{2} \mathrm{O}\right)\left(\mathrm{L}_{2}\right)\right]\left(2^{\prime}\right)$ (red line), 1,10-Phenanthroline (green line) and a $\mathrm{MnF}_{3} \cdot 3 \mathrm{H}_{2} \mathrm{O} / \mathrm{KBr}$ mixture (black line).

FT-IR and Raman spectra were obtained from complexes 3-6 along with their corresponding ligands $\left(\mathrm{L}_{3}-\mathrm{L}_{6}\right)$. Overlays of these plots are given in the supplementary information (Figures S17S25) and show similar and consistent trends with the corresponding data obtained from complexes $\mathbf{1}^{\prime}$ and $\mathbf{2}^{\prime}$. We were unable to locate literature values for the Raman bands associated with 6-methyl-2,2'-dipyridyl $\left(L_{3}\right), 4,4$ '-dimethyl,2,2'dipyridyl $\left(L_{4}\right)$, 5,5-dimethyl-2,2'-dipyridyl $\left(L_{5}\right)$ and 5-chloro-1-10phenanthroline $\left(L_{6}\right)$, however our data on $L_{3}-L_{6}$ were found to be consistent with data from 2,2'-bipyridyl $\left(L_{1} c f\right.$. $\left.L_{3}-L_{5}\right)$ and 1,10'phenanthroline $\left(\mathrm{L}_{2} c f\right.$. $\left.\mathrm{L}_{6}\right)$, respectively.

\section{Conclusions}

We have demonstrated a new and facile synthetic route to a family of $\mathrm{Mn}(\mathrm{III})$ monomers with general formula $\left[\mathrm{MnF}_{3}\left(\mathrm{H}_{2} \mathrm{O}\right)\left(\mathrm{L}_{1}\right.\right.$. 6)]. Magnetic susceptibility and magnetisation studies along with MF / HF-EPR spectroscopy were successfully employed to elucidate their $D$-tensor parameters, which are in line with each other and commensurate with literature values. Raman spectroscopy was also used to look at $\mathrm{Mn}-\mathrm{F}$ vibrational modes and subsequently compared to literature values. Work is currently underway on using $\mathbf{1}^{\prime}-\mathbf{6}$ as presursors to discrete polymetallic cages and as building blocks to 1-3D extended architectures using self-assembly routes. Investigations into their potential catalytic ability are also ongoing.

\section{Experimental Section}

All reagents and solvents were purchased commercially and used as supplied. Take caution when handling $\mathrm{MnF}_{3}$ and heating solvent solutions. All manipulations were carried out in a fumehood and protective clothing was used throughout.

\section{General synthesis of $\left[\mathrm{Mn}(\mathrm{III}) \mathrm{F}_{3}\left(\mathrm{H}_{2} \mathrm{O}\right)\left(\mathrm{L}_{1-6}\right)\right]$}

$\mathrm{Mn}$ (III) $\mathrm{F}_{3}(0.5 \mathrm{~g}, 4.46 \mathrm{mmol})$ and one equivalent of ligand ' $\mathrm{L}_{x}$ ' were dissolved in $25 \mathrm{~cm}^{3} \mathrm{MeOH}$. The subsequent methanolic solution was warmed (with rapid stirring) on a heating mantle in a fumehood until the solution was simmering $\left(\sim 50^{\circ} \mathrm{C}\right)$. The solution was removed from the heat source using forceps as soon as a dark red colour was obtained. The resulting solution was then filtered upon cooling and X-ray quality crystals of 1'-6 were obtained upon slow evaporation of their mother liquors. Full details are available in the ESI.

\section{Single crystal X-ray structure determination}

The structures of 1'-6 were collected on an Xcalibur $S$ single crystal diffractometer (Oxford Diffraction) using an enhanced Mo source. Each data reduction was carried out on the CrysAlisPro software package. The structures were solved by direct methods $(\mathrm{SHELXS}-97)^{[31]}$ and refined by full matrix least squares using SHELXL-97. ${ }^{[32]}$ SHELX operations were automated using the OSCAIL software package. ${ }^{[33]}$ All non-hydrogen atoms were refined as anisotropic. The hydrogen atoms belonging to the bound water molecules in 1'-6 were located in the difference map. All other hydrogens were placed in calculated positions. The two waters of crystallisation in $\mathbf{4}$ were refined as anisotropic. The $\mathrm{MeOH}$ (labelled $\mathrm{C} 13-\mathrm{O} 2$ ) solvent molecule in $\mathbf{5}$ was modelled as disordered over two sites with 50:50 occupancy, while its associated proton ( $\mathrm{H} 2)$ was placed in a calculated position lying along an appropriate direction at a distance of 1.849 Å from F3. CCDC numbers: 1489265 (1') - 1489270 (6).

\section{MF / HF-EPR spectroscopy}

MF / HF-EPR measurements were performed on a multifrequency spectrometer ${ }^{[34]}$ operating in a double-pass configuration. A $110 \mathrm{GHz}$ frequency source (Virginia Diodes Inc.) is multiplied by a doubler or a tripler to obtain 221 or 331 $\mathrm{GHz}$, respectively. The 460 and $575 \mathrm{GHz}$ spectra were obtained using a $115 \mathrm{GHz}$ Gunn oscillator (Radiometer Physics $\mathrm{GmbH}$ ) together with a quadrupler or a quintupler. The detection is performed with a hot electron InSb bolometer (QMC Instruments). The exciting light is propagated with a QuasiOptical set-up (Thomas Keating) outside the cryostat and with the help of a corrugated waveguide inside it. The main magnetic field is supplied by a $16 \mathrm{~T}$ superconducting magnet associated to a VTI (Cryogenic). The measurements were done on 
powdered samples pressed into pellets in order to limit torqueing effects. Calculated spectra were obtained with the SIM program $^{[35]}$ from $\mathrm{H}$. Weihe (Univ. of Copenhagen).

\section{Other measurements}

Elemental analyses were carried out at the School of Chemistry, NUI Galway. Magnetic susceptibility measurements were obtained using a Quantum Design SQUID magnetometer in an applied field of $1000 \mathrm{G}$. Diamagnetic corrections were estimated from Pascal's constants. All measured complexes were set in eicosane to avoid torqueing of the crystallites. All magnetic samples were collected as single-crystalline products and analysed using microanalysis and IR measurements prior to their magnetic assessment. If necessary, phase purity between cross-batches were validated using unit cell checks and IR measurements.

Infra-red spectra were recorded on a Perkin Elmer FT-IR Spectrum One spectrometer equipped with a Universal ATR Sampling accessory. Raman measurements were recorded at room temperature using a Raman WORKSTATION ${ }^{\mathrm{TM}}$ Analyzer with PhAT imaging probe (Kaiser Optical Systems, Inc.) with 785 $\mathrm{nm}$ excitation. An exposure time of $10 \times 8$ seconds was used and spectra were collected from 250 to $4000 \mathrm{~cm}^{-1}$ (at a resolution of $5 \mathrm{~cm}^{-1}$ ). Raman spectra of the coloured complexes 1'-6 were collected from a solid dispersion (approximately 1.5\% by weight of complex) in dry $\mathrm{KBr}$ which was pressed into a disk using a hydraulic press and a $13 \mathrm{~mm}$ die set. This was done to minimise sample burning due to excessive absorption of excitation light. All data were normalised to the peak of maximum intensity and baseline corrected using standard methods.

\section{Acknowledgements}

The authors would like to thank the IRSCET Embark Fellowship (EH) and the EPRSC (SS and EKB) for funding. We would also like to thank the EPSRC National EPR Service for their assistance (EJLM, DC).

Keywords: Molecular Magnetism • Electron Paramagnetic Resonance $\cdot$ Zero-field splitting $\bullet \mathrm{Mn}(\mathrm{III}) \mathrm{F}_{3} \cdot \mathrm{D}$-tensor.

[1] Commercially available salts include $\mathrm{Mn}(\mathrm{acac})_{3}$ (where acac = acetylacetonate), $\mathrm{Mn}_{2} \mathrm{O}_{3}$ and $\mathrm{Mn}(\mathrm{OAc})_{3} \cdot 2 \mathrm{H}_{2} \mathrm{O}$ (although in reality the latter has the trinuclear formula $\left.\left[\mathrm{Mn}(\mathrm{III})_{3} \mathrm{O}(\mathrm{OAc})_{6}(\text { solvent })_{3}\right](\mathrm{OAc})\right)$.
[2] For a suitable review on the role of manganese(III) acetate in organic synthesis see: M. Mondal, U. Bora. RSC Advances. 2013, 3, 18716-18754.

[3] B. B. Snider. Chem. Rev., 1996, 96, 339-363.

[4] a) E. J. Larson, V. L. Pecoraro. Manganese Redox Enzymes, ed. V. L. Pecoraro, VCH Publisher, Inc., New York, 1992, p. 1. b) M. J. Gunter, R. Turner. Coord. Chem. Rev., 1991, 108, 115. c) A. Galstyan, A. Robertazzi, and E. W. Knapp. J. Am. Chem. Soc. 2012, 134, 7442-7449.

[5] a) S. P. H. Mee, V. Lee, J. E. Baldwin. Angew. Chem. Int. Ed., 2004, 43, 1132-1136. b) S. P. H. Mee, V. Lee, J. E. Baldwin. Chem. Eur. J. 2005, 11, 3294-3308. c) M. Herve, G. Lefevre, E. A. Mitchell, B. U. W. Maes, A. Jutand. Chem. Eur. J. 2015, 21, 18401-18406.

[6] a) C. Amatore, A. Jutand, G. Le Duc. Angew. Chem. Int. Ed., 2012, 51, 1379-1382. b) C. Amatore, G. Le Duc, A. Jutand. Chem. Eur. J. 2013, 19, 10082-10093.

[7] C. Amatore, L. Grimaud, G. Le Duc, A. Jutand. Angew. Chem. Int. Ed. 2014, 53, 6982-6985.

[8] a) Molecular Magnetism, O. Kahn. Wiley Publishing. 1993, b) Molecular Nanomagnets, D. Gatteschi, R. Sessoli and J. Villain. Oxford Press., 2006. c) Molecular Cluster Magnets., World Science Series in Nanoscience and Nanotechnology.-Vol. 3. R. E. P. Winpenny. World Scientific Publishing., 2012.

[9] G. Aromi, E. K. Brechin. Struct. and Bonding. Springer. Chapter 1. p.1 - 67.

[10] N. V. Gerbeleu, Yu. T. Struchkov, G. A. Timco, A. S. Batsanov, K. M. Indrichan, G. A. Popovich, Dokl. Akad. Nauk. SSSR, 1990, 313, 1459.

[11] M. L. Baker, G. A. Timco, S. Piligkos, J. M. Mathieson, H. Mutka, F. Tuna, P. Kozlowski, M. Antkowiak, T. Guidi, T. Gupta, H. Rath, R. J. Woolfson, G. Kamieniarz, R. G. Pritchard, H. Weihe, L. Cronin, G. Rajarman, D. Collison, E. J. L. McInnes, R. E. P. Winpenny. P. Nas. Acac. Sci., 2012, 109(47), 1911319118.

[12] E. J. L. Mclnnes, S. Piligkos, G. A. Timco, R. E. P. Winpenny. Coord. Chem. Rev., 2005, 249, 2577-2590.

[13] F. A. Larsen, E. J. L. McInnes, H. El Mkami, J. Overgaard, S. Piligkos, G. Rajaraman, E. Rentschler, A. A. Smith, G. M. Smith, V. Boote, M. Jennings, G. A. Timco, R. E. P. Winpenny. Angew. Chem. Int. Ed., 2003, 42, 101-105.

[14] a) S. A. Oschsenbein, F. Tuna, M. Rancan, R. S. G. Davies, C. A. Muryn, O. Waldmann, R. Bircher, A. Sieber, G. Carver, H. Mutka, F. FernandezAlonso, A. Podlesnyak, L. P. Englehardt, G. A. Timco, H. U. Güdel, R. E. P. Winpenny. Chem. Eur. J. 2008, 14, 5144-5158. b) L. P. Englehardt, C. A. Muryn, R. G. Pritchard, G. A. Timco, F. Tuna, R. E. P. Winpenny. Angew. Chem. Int. Ed., 2008, 47, 924-927. c) F. A. Larsen, J. Overgaard, S. Parsons, 
E. Rentschler, A. A. Smith, G. A. Timco, R. E. P. Winpenny. Angew. Chem. Int. Ed., 2003, 42, 5978-5981.

[15] K. S. Pedersen, G. Lorusso, J. J. Morales, T. Weyhermüller, S. Piligkos, S K. Singh, D. Larsen, N. Schau-Magnussen, G. Rajaraman, M. Evangelisti, J. Bendix. Angew. Chem. Int. Ed. 2014, 53, 2394-2397.

[16] M. N. Bhattacharjee, M. K. Chaudhuri, R. N. Dutta, Purkayatsha., Inorg. Chem., 1989, 28, $3747-3752$.

[17] P. Núñez, C. Elias, J. Fuentes, X. Solans, A. Tressaud, M. C. Marco de Lucas, F. Rodrigues., Dalton. Trans., 1997, 4335-4340.

[18] A. R. Biju, M. V. Rajasekharan. J. Mol. Struct. 2008, 875, 456-461.

[19] a) L. F. Jones, J. Raftery, S. J. Teat, D. Collison, E. K. Brechin. Polyhedron, 2005, 24, 2443. b) L. F. Jones, G. Rajaraman, J. Brockman, M. Murugesu, E. Carolina Sańudo, J. Raftery, S. J. Teat, W. Wernsdorfer, G. Christou, E. K. Brechin, D. Collison. Chem. Eur. J., 2004, 10, 5180-5194. c) L. F. Jones, E. K. Brechin, D. Collison, J. Raftery, S. J. Teat. Inorg. Chem., 2003, 42, 6971-6973. d) L. F. Jones, E. K. Brechin, D. Collison, A. Harrison, S. J. Teat, W. Wernsdorfer, Chem. Commun., 2002, 24, 2974-2975.

[20] W. H. Press, S. A. Teukolsky, W. T. Vetterling, B. P. Flannery, "Numerical Recipes in C: The Art of Scientific Computing". Second Edition, Cambridge, Cambridge University Press, 1992.

[21] C. Mantel, A. K. Hassan, J. Pécaut, A. Deronzier, M.-N Collomb, C. A. Duboc-Toia,. J. Am. Chem. Soc., 2003, 125 (40), 12337-12344.

[22] Z. Mazej, Journal of Fluorine Chemistry 2002, 114, 75-80.

[23] a) W. Sawodny, K. M. Rau. J. Fluor. Chem., 1993, 61, 111-116. b) M. Adelhelm, E. Jacob. J. Fluor. Chem., 1991, 54, 21.

[24] M. Molinier, W. Massa. J. Fluor. Chem., 1992, 57, 139-146.
[25] A. Cua, D. H. Stewart, M. J. Reifler, G. W. Brudvig, D. F. Bocian. J. Am. Chem. Soc., 2000, 122, 2069-2077.

[26] E. Castellucci, L. Angeloni, N. Neto, G. Sbrana, Chemical Physics, 1979, 43, 365-373S.

[27] Umapathy, G. Lee-Son, R. E. Hester, Journal of Molecular Structure 1989, 194, 107-116.

[28] M. Kim, K. Itoh, Journal of electroanalytical chemistry and interfacial electrochemistry 1985, 188, 137-151.

[29] M. Reiher, G. Brehm, S. Schneider, The Journal of Physical Chemistry A 2004, 108, 734-742.

[30] D. A. Thornton, G. M. Watkins, Spectrochimica Acta Part A: Molecular Spectroscopy 1991, 47, 1085-1096.

[31] G. M. Sheldrick, Acta. Crystallogr., Sect. A: Found. Crystallogr., 1990, A46, 467.

[32] G. M. Sheldrick, SHELXL-97, A computer programme for crystal structure determination, University of Gottingen, 1997.

[33] P. McArdle, P. Daly, D. Cunningham, J. Appl. Crystallogr., 2002, 35, 378.

[34] A. L. Barra, A. K. Hassan, A. Janoschka, C. L. Schmidt, V. Schünemann, Appl. Magn. Reson., 2006, 30, 385-397.

[35] J. Glerup, H. Weihe, Inorg. Chem., 1997, 36, 2816-2819. 
Entry for the Table of Contents (Please choose one layout)

Layout 1:

\section{FULL PAPER}

We report a rapid and facile synthetic route to the synthesis of a family of $\mathrm{Mn}$ (III) monomers of general formula $\left[\mathrm{Mn}(\mathrm{III}) \mathrm{F}_{3}\left(\mathrm{H}_{2} \mathrm{O}\right)\left(\mathrm{L}_{1-6}\right)\right]$. Magnetic susceptibility and magnetisation experiments along with multifrequency / high-field EPR were employed to elucidate anisotropic $D$ tensors. The terminal Mn-F vibrational stretches have been probed using Raman spectroscopy.

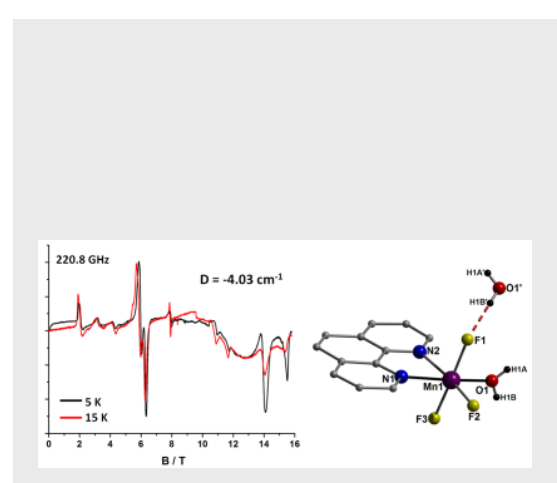

MF / HF-EPR

Edel Houton, Brian Kelly, Sergio Sanz, Eric J. L. Mclnnes, David Collison, Euan K. Brechin, Anne-Laure Barra, Alan G. Ryder and Leigh F. Jones.

Page No. - Page No.

A Facile Synthetic Route to a Family of Mn(III) Monomers and their Structural, Magnetic and Spectroscopic Studies 